\title{
The Contribution of Women in the Bengali Language Movement (1952): A Historical Analysis
}

\author{
Md. Rajaul Karim ${ }^{1}$ and Md. Shaon Akter ${ }^{2}$ \\ ${ }^{1}$ Bangladesh Studies, Khwaja Yunus Ali University, Sirajgonj, Bangladesh and ${ }^{2}$ Department of English, Khwaja Yunus Ali \\ University, Sirajgonj, Bangladesh. \\ *Correspondence: mdrezaulkarim801@gmail.com (Dr. Md. Rajaul Karim, Senior Lecturer, Bangladesh Studies, Khwaja \\ Yunus Ali University, Sirajgonj, Bangladesh).
}

\begin{abstract}
During the period 1947-48, student movements started in various areas of Bangladesh demanding to make Bengali one of the state languages. Through participation in these movements, political awareness among the girls of Bengal increased. So in the final stages of the 1952 language movement, the massive participation of girls can be noticed. The girls of Dhaka and the girls of different districts and sub-divisional cities of Bangladesh took active part in 1952 of language movement. In addition to school-college girls, various members of various women's organizations such as Shishuraksha Samiti, Wari Mahila Samiti and others actively take part in 1952 of language movement. Therefore, the role of Bengali women in the Bengali language movement was unforgettable. Apart from men, women also acted as supporting forces of the language movement in various ways from their position. Therefore, the idea which Bengali women are just helpless, helpless is not correct. In this article we have analyzed the role of women in Bengali language movement.
\end{abstract}

Keywords: Patriotism, Historical analysis, Contribution, Language movement, and Women's contribution.

\section{INTRODUCTION:}

In the late nineteenth century, women's awareness had increased. That is why, when the province of Bengal was divided in 1905, the achievements of the women of Bengal were not less in the unprecedented Swadeshi movement that spread across Bangladesh. From the early of the Swadeshi movement, the women society has been providing special supplies to this movement. At this time they gathered in their homes, in the countryside, committed to the introduction of indigenous goods and pledged to weigh British goods. During the British rule, the rural women's society actively took part in the peasant movement in Bengal and showed immense courage and determination in leading the movement, in the resistance struggle and in UniversePG I www.universepg.com dealing with the enemy. The Tank, Nankar and Tebhaga movements that started in different districts of West and East Bengal in the thirties and forties of the twentieth century's were on the one hand a resistance struggle against the exploitation of zamindar jotdars and on the other a special step in the freedom struggle against the British Raj. Movement participated in the struggle (Sultana and Amin, 2020).

Just when the peasant society was oppressed by the police torture, arrests and the terrorist oppression of the zamindars, the peasant women formed peasant organizations along with the men to protest. Along with building their own resistance forces, they have always had the courage to side with men in order to 
strengthen the movement. By spontaneously participating in various peasant meetings, above all, by overcoming all obstacles, by engaging in direct struggle with infinite courage, by giving his life, he has glorified the history of peasant revolt. The role of women in various stages of the movement against the Pakistani regime was noteworthy.

Despite the positional weakness, exploitation, backwardness, disrespect and disenfranchisement of women in the society, women actively take part in every movement of Pakistan period along with men from different political parties or by establishing different women's organizations. Among the women who participated in all these movements were progressive women of various levels including school-college and university students. It is noteworthy that since the fifties, women have come forward in politics by organizing through organizations. That is why, most of the organizations are not limited to social services but also establish their rights and demands such as increasing the opportunities and rights of women, rights to all kinds of property including agricultural land, discouraging polygamy, controlling arbitrary divorce, making marriage registration compulsory, Determining the age of the girl to be 16 and the age of the boy to be 21 , to make the mohrana compulsory to ensure the safety of the girls etc. they have actively participated in various movements in the crisis of politics of the country in the contemporary period as they have done in the movement. After establishing Pakistan in 1947, Bengali women spontaneously participated in all the movements that started in the country to protect the mother tongue and to break the shackles of Pakistan's misrule.

\section{Historical background of women's movement in Bengal}

The common notion is that Bengali women are helpless. They endured all the oppression with open mouth. But reviewing the history, it is understood that the need for Bengali women has come to the fore. In the past, there have been instances of active participation of women in various movements. Women's rights are the work done to ensure the dignity of women and men in the family, society and the state (Parveen, 2010). The goals and activities of the women's movement vary by country, class, race and UniversePG I www.universepg.com culture. The women's movement in the Indian subcontinent, especially in undivided Bengal, began as part of the reformist movement and modernization. Progressive leaders of the social reform movement Raja Rammohun Roy, (1774-1833), Ishwarchanda Bidasagar, (1820-1891) and British scholar Derozio, Braksamaj leaders started a mass movement to protect women from religious and social oppression. However, this movement was to liberate women from the oppression of religion and culture. But the main step of the women's movement was the education movement (Symonds, Richard, 1915; Sarkar, 1972; Karim et al., 1916). It was through this education movement that the renaissance of women began. With the enactment of Wood's Despace in 1854, the pace of women's education in Bengal increased. In the early nineteenth century, educated Bengali women became aware of their rights. The participation of women in the National Congress began. This gives more opportunities to Bengali women to participate in politics. When the British partition plan was implemented in 1905, the women of Bengal took part in the antipartition movement led by the Congress. MontagueChelmsford came to India in December 1917 (Ali, 1965). An all-India women's delegation led by Sarojini Naidu demanded their inclusion as women voters and Congress supports this claim. Consequently women gain the right to vote. Later, the women of Bengal were outraged by the inspiration of Mahatma Gandhi Participates in politics.

In the caliphate-non-cooperation movement, women of Bengal participated spontaneously along with men. In 1928, Mahila Rashtriya Sangha was formed under the leadership of Latika Ghosh (Amin, 1996). It was the only regular organization of women in politics. After that, women's volunteer groups, women's associations etc. were formed in various movements and struggles. The role of these organizations in the anti-British movement was unique. Grameen Nari Samaj took an active part in the peasant movement in Bengal and showed immense courage and determination in leading the movement and in the struggle against resistance. Tank, Nankar and Tebhaga movements started in different districts of Bengal from the thirties to the forties of the twentieth century (Falguni, 1997). These movements were on the one hand a deterrent against 
the exploitation of the zamindar landlords and on the other hand a special step in the freedom struggle against the British Raj. The peasant society protested against the police torture, arrests and oppression of the zamindars that is why they formed their own resistance forces. These women have overcome all obstacles and joined the direct struggle with infinite courage and have given their lives to the history of the peasant revolt. Pakistan was established on 14 August 1947 (Nanda, 1975). But the hopes and aspirations with which Pakistan was established did not materialize. On the contrary, the existing disparity between the two parts of Pakistan is increasing day by day. At first a bloody movement was organized on the question of what would be the state language of Pakistan. Men as well as women participate in a bloody movement (Bose, 1974).

\section{Fill in the gaps in the research field}

None of the published books and articles on the important contribution of women in the Bengali language movement has found a place for research analysis. In other words, in the books and articles published on the Bengali language movement, in most cases, some issues have been discussed sporadically from a general point of view. Therefore, I have written this article realizing the need for important research on women in Bangladesh in the Bengali language movement.

\section{Research methods and data collection}

Basically I have collected information from primary sources. Newspapers and periodicals are important elements of the language movement. Data has also been collected from various Bangla language programs aired on Bangladesh Radio, BTV and BBC. Moreover, I have collected information's by attending the meetings and conventions of various women's organizations. I have interviewed the women participating in the language movement for the purpose of providing information on the role of women in the language movement.

\section{The purpose of the study}

The purpose of this study is to examine the role of Bengali women's society at different stages of the language movement during the Pakistan period. Despite the positional weakness, exploitation, back- wardness, disrespect and disenfranchisement of women in the society, women society participates in the language movement by establishing various women's organizations under different political parties. Among the women who participated in the movement were progressive ordinary women of different levels including school, college and university students.

\section{Women in the language movement}

Pakistan was created on 14th August 1947. Soon after the establishment of Pakistan, the Western ruling clique first attacked the Bengali mother tongue. This created intense anger among the common people and educated people of East Bengal. The movement started with a new initiative to protect the mother tongue. The women of Bengal are engaged in direct struggle to achieve this huge goal (Umar, 1979). Since July 1947, Zia Uddin Ahmed, Vice-Chancellor of Aligarh University, Chowdhury Khalequzzaman, a member of the Muslim League's Walking Committee, and Nadia Sa,d Ahmed have proposed Urdu to establish the state language of Pakistan in various papers and seminars. In the wake of this announcement, many women of this country protested and spoke in favor of the Bengali language (Helal, et al., 1984). Hamida Selim, a student of Michael Madhusudan College and a student federation activist, wrote in a letter to Swadhinata, the mouthpiece of the Communist Party, published from Calcutta on July 10, protesting the efforts of anti-Bangla speakers in East Pakistan (Hannan, 1986).

As Bengalis, we claimed the whole of Bengal within East Pakistan. Similarly, why shouldn't I claim Bengali as the state language of East Pakistan as the language of Bangladesh today? It is very sad to see the argument against making Bengali the state language on the page of popular East Pakistani daily Azad.... Today we have to forget all the literary art of Bengalis? How can we forget the translation of the Qur'an written by the human Akram Khan, how can we forget the Mustafacharit written by him, how can we forget our Nazrul song .... Do you have to believe that the language spoken by four and a half crore people of Bengal, the language in which literature is written, the language in which they express their thoughts will not be their own language? Would it be right 
that their lives would have nothing to do with the state language of independent Pakistan? (The Holiday, February 19, 1988).

On 2 September 1947, with the formation of a cultural body called 'Tamuddan Majlis' in Dhaka on the question of whether the state language of Pakistan was Bengali or Urdu, the "Rashtrabhasha Sangram Parishad" was formed in Sylhet in support of the Bengali language. Many women including Mrs. Jobeda Khatun, Hajera Mahmood, Rokeya Begum have played important roles in this state language struggle council (Parveen, 2010). Ayesha Begum's discussion on language issues was published in Azad newspaper on 5 October 1947. From this time onwards, Bengal women became more active in the social language movement and they started demanding Bengali as the state language of Pakistan in various meetings and rallies (Helal et al., 1984). At the meeting organized by Tamaddun Majlis on 13 November 1947, Mr. Leela Roy made an important speech on the question of language (The Holiday, February 19, 1988). The following report was published in Azad newspaper on 18 November 1947. It is written, "A memorandum has been submitted to the Prime Minister of East Bengal requesting to declare Bengali as the state language of East Pakistan. Hundreds of citizens of East Pakistan have signed it. Among them were writers, poets, artists, musicians, lawyers, professors, ulama, students, political leaders, doctors, and women. Among the women who signed it were Shamsunnahar Mahmud, Mrs. Leela Roy, Jayshree, Mrs. Anwara Chowdhury" (Helal et al., 1984).

It is noteworthy that the language proposal or movement came before Pakistan became independent. The movement at that time was limited to newspaper statements and discussions. Then on 11 January 1948, when the Minister of Communications of Pakistan, Abdur Rob Nishtar, visited Sylhet, a delegation from Sylhet met him and demanded that Bengali be made the state language of East Pakistan (Mumtaz et al., 1987). 22 February 1948 Sylhet Women's League District Committee President Begum Jobeda Khatun Chowdhury along with President Syeda Shah Banu, Editor Syeda Lutfunnesa Khatun, Headmaster of Sylhet Royal Girls School Rabia Khatun, Jahanara Matin, Rokeya Begum, Samsi Qaisun, Shamsunnesa UniversePG I www.universepg.com
Khatun and many other women in a memorandum sent to East Pakistan Chief Minister Khwaja Nazimuddin demanded that Balabhasa be the state language of East Pakistan (Islam, 1994). This effort of the women of Sylhet to protect the dignity of mother tongue Bengali is very noteworthy. Abul Kashem, the secretary of Tamaddun Majlis, sent a congratulatory letter to Jobeda Khatun, the president of Mahila League. Wrote the letter, "Today we are truly experiencing unprecedented joy and infinite glory, you have done what the men of Sylhet could not do" (The Sunday, February 22, 1987).

On 25 February 1948 in Rajshahi, on 28 February 1948 in Dinajpur, Pabna, Munshiganj, students of schools and colleges marched around the city demanding Bangla language and marching in huge processions (Umar, 1979). On 28 February 1948, Hajera Mahmud and Laila Azumand Banu, one of the delegates from East Pakistan to the Southeast Asian Youth Conference, issued a statement in Calcutta supporting the East Bengal language movement and protesting Nazimuddin's statement to the Constituent Assembly (Mankeker, 1971). On March 10, 1948, a meeting was convened by the Govinda Park Sylhet District Muslim Women's League in Sylhet, which caused a great stir among the people. Islam declared all the meetings and gatherings held in support of Bengali language in Sylhet closed for two months (Umar, 1979).

A meeting of cultural and political committees was held at Fazlul Haque Hall on 2 March with the joint initiative of East Pakistan Muslim Student League, student leaders of different halls of Dhaka University and Tamaddun Majlis to form an active movement against the decision of the Constituent Assembly and anti-Bangla activities of the Muslim League. An allparty council called 'Rashtrabhasha Sangram Parishad' was formed with the aim of keeping the language movement active and Anwara Khatun and Lily Khatun played an important role in this meeting on behalf of women (Haque et al., 1991). When a general strike was called in the whole of East Bengal on 11 March 1948, Unme Batul Khaleda Khanam, a final year student, clashed with police when a group of girls came to the High Court to protest, injuring several people (Shamsuzzaman, 1992). Hosne Ara Begum, a 10th class student of Pirojpur Urban Girls School, 
played an important role in the school strike on 11 March 1948. The students of Pirojpur Gals School decided to hold a strike on March 11 in Dhaka and other parts of the country to demand the language (Ayoob, 1971).

Rahima Khatun and Saleha Khatun, two leaders of the Rashtrabhasha Sangram Parishad, played an important role during the strike in Bogra on 11 March 1948. Under their leadership, school-college students marched around the city (Haque et al., 1991). A full-scale strike was observed in every school-college of Jessore district and on that day women led by Hamida Rahman, the joint convener of Jessore District Rashtrabhasha Sangram Parishad, took out a procession (Umar, 1979).Tying rally in the face of police began to clash. When the women are in danger in the clash, the women of the brothel in Jhalaipatti are also involved. The girls took refuge in the brothel without getting any change (Hannan, 1986). Participated in the women's movement led by Fatema Chowdhury, a member of the Khulna Girl's Guide and Women's Self-Defense Association during the state language Bangla Chai movement. Processions and meetings continued in the city in support of the movement (Fatema Chowdhury's interview on 25 May 1998).

On 14 March 1948 strikes were observed all over Bengal. The strike was so intense that on March 15, the Prime Minister summoned General Officer Commanding Ayub Khan. In a speech to the Constituent Assembly on that day, Anwara Khatun demanded that the Prime Minister take a closer look at the situation. Let's go there and see (Zamal, 1971). Prime Minister Khwaja Nazimuddin became terrified of the student movement. He invited Governor General Mohammad Ali Jinnah to visit Dhaka. In response to his call, Jinnah came to Dhaka on 17 March 1948.Jinnah declared Urdu the state language of Pakistan at a public meeting on March 21, 1948 at the Racecourse Ground in Dhaka (Helal et al., 1984). On 24 March 1948, at the convocation ceremony of Dhaka University, he again declared Urdu as the state language of Pakistan. The students present at the announcement strongly protested. The rest of Jinnah left Dhaka. After Jinnah's movement to leave Dhaka came to a standstill (Islam et al., 1984). The language movement reached its climax on 21 February 1952. The participation of UniversePG I www.universepg.com women in this movement was an important chapter. Women's political awareness increases through participation in the movement (Makinley, 1979).

On 30 January 1952, the University Rashtrabhasha Sangram Parishad announced a program of student strikes, meetings and processions in Dhaka city on 4 February to protest against the introduction of Bengali as the only state language of Pakistan and Arabic script (Islam, 1984). As a result, on 4 February 1952, the students staged a strike in Dhaka city to make the preannounced program a success. During the strike, several students led by Eden College student Sharifa Khatun left the hall and joined the movement (Helal, 1984). At the end of the meeting a procession of more than three hundred women came out. The procession demanded that Bengali be declared the state language of Pakistan. In addition to holding strikes, rallies and processions on February 4, 1952, preparations began for the celebration of Protest Day on February 21(The Sunday, February 22, 1987). Flag Day was declared on 11, 12 and 13 February 1952 to spread the movement throughout the province. During this time Nadia Begum and were responsible for writing 500 posters. Nadia Begum and Shafia write posters with their girlfriends and other women (Parveen, 2010). Nurunnahar Kabir's handwriting was beautiful and he was responsible for writing most of the posters. He was assisted by many other women including Raushan Ara Bachchu (Choudhury, 1974). Mahfil Ara, Rabia Islam, Nurjahan Begum, Sufia Khatun, Kaiser Lily and others were responsible for writing posters in Dhaka University (Matin, Abdul and Rafiq,Ahmad,1991). Posters and festoons were made all night on February 20 to make the February 21, 1952 program a success (Begum, 1989).

When Abdul Matin, the convener of the Rashtrabhasha Sangram Parishad of Dhaka University, called for raising money to spread the movement across the country, a group of women led by Rokeya was able to raise 10,000 taka in a nearby colony (Helal et al., 1984 \& Parveen, 2010). Apart from the students, members of various women's organizations, especially the Child Protection Association and Wari Women's Association, actively participated in the language movement, distributed leaflets of the All-Party Language Struggle Council in different parts of the country and 
held meetings at various places to protest against Urdu declaring state language (Kamal, 1987). Ignoring the government's policy of repression, Begum Sufia Kamal, Kamrunnahar Laili, Halima Khatun, Nurjahan Moshed, Afsari Khanam addressed various meetings and called for the unity of women in favor of the state language Bengal (The Sunday, February 22, 1987). On 17 February 1952, outside Dhaka, Nilphamari, Brakshanbaria, Madaripur, Rangpur and other parts of the country, men as well as women took part in processions and demonstrations in favor of the Bengali state language (Ahmed, Monwar, 1993). Shafia, Halima Khatun, Sufia Khan, Amena Mahmud, Shamsun Nahar, Sufia Ibrahim, Raushan Ara Bachchu and others called for participation in the struggle of schoolcollege girls with the aim of making the movement more dynamic. In response to their call, students of Muslim Girls School, Eden College participated in the protest. On 21 February 1952, 25/30 students of Muslim Gals High School, led by Halima Khatun and Kamrunnesa and Taifur, staged an anti-Pakistan protest and vowed to continue the movement till Bengali was declared the state language (Helal et al., 1984). Sufia Karim, general secretary of the Student Parliament of Eden College, rallied the students of Anandamoyee Girls High School to take part in the protest and held anti-government talks with them on February 21 to demand the establishment of Urdu as well as Bengali as the state language of Pakistan (Parveen, 2010).

In order to establish Bengali as the state language, Gaziul Haque and Mohammad Sultan along with a few others decided to break section 144 announced by the government on the morning of 21 February. Jahanara Laiju, an eighth grader, played an important role in sending this letter (Kamal, 1987). On the morning of $21^{\text {st }}$ February, the girls in charge divided the schoolcollege girls according to the designated area and brought them to the Amtala meeting of Dhaka University. The general student meeting started at around 11 in the afternoon under the chairmanship of Gaziul Haque (Choudhury, 1972 and Deshpande, G.P., 1971). But the girls, led by Shafia, boycotted the meeting due to the controversy over the violation of section 144. They were basically in favor of breaking section 144 (Parveen, 2010). Thinking that the situ- ation was not favorable, Raushan Ara ordered the girls to return home. But the girls did not return home to attend the meeting and vowed to continue the movement until the state language was conquered (Kamal, 1987).

In the end, the decision of a large number of students in favor of breaking Section 144 was accepted as final. According to the final decision, a group of 10 students will join the procession in violation of Section 144 (The Azad, February 22, 1952). Attempts were made to divide the group into groups. Armed police lined up in front of the university gate and arrested the boys as soon as they left. As the boys' group began to make arrests, three groups of girls, led by Shafia and Raushan Ara Bachchu, marched in procession. They thought that in the conservative environment of that time, the police would not beat the girls with sticks. But as soon as the procession of girls reached the entrance of Dhaka Medical College, the police started beating them. Many girls including Raushan Ara Bachchu were injured by the police batons. In the face of police obstruction, the injured girls defended themselves in SM Hall of Dhaka University. The provost of the hall, Osman Gani, took refuge on the verandah of his residence (Ahmed, 1993).

At this time the police set up a barricade at the gate of the Medical College so that the girls could not participate in the meeting held at Dhaka University. But when the girls broke through the barricades and marched towards the meeting, the police first used batons and then fired blank shots. Many girls were seriously injured. The injured girls were sent to the hospital. Later the situation calmed down, the girls were able to return to the hall with the help of Monir Chowdhury (Asaduzzaman, 1989). It is to be noted that the female students of various educational institutions of Dhaka played a leading role in the success of the program announced on 21 February 1952. The female students of Dhaka University in particular were able to break the 144 section and take out a procession which is an important event in the history of language movement (Monowara Begum on 16 August 1998). During the movement, Mrs. Usha Bepari was a student of the nurse education department of Dhaka Medical College. He assisted the doctors in treating the injured students in the movement. After 
the students took refuge in the hospital to avoid police arrest, Mrs. Usha Bepari laid the students in the hospital bed and introduced them to the police as patients. His efforts enabled the students to avoid arrest. When the police imposed curfew at night, Usha Bepari helped the students to escape from the hospital in white clothes. Usha also took an active part in the construction of the Shaheed Minar for the language martyrs. Thus the nurse student made an important contribution to the language movement (The Azad, February 24, 1952). Apart from Dhaka, the program was celebrated on February 21 in different parts of the province.

On 21 February 1952, Begum Monowara Ahmed, an educator at Jhenaidah Girls' School in Jessore district, led by Hasna and Bella, took part in the procession for the first time and violated Section 144 (Hannan, Mohammad, 1986). The strike was successfully observed in Rajshahi on 21 February 1952. At 4 pm, Bhuvan Mohan Pak's public meeting was attended by Monwara Begum, a 10th class student of PN Gals School and Hafiza Begum Tuku, a $9^{\text {th }}$ class student and many others. At the meeting, Rashtrabhasha adopted several proposals in favor of Bangla (Singh, Khushwant, 1976). On 21 February 1952, the Women's Language Movement Association was formed in Natore.Protest processions and meetings were held at Mr. Chowdhury's ground on the initiative of the association. It was presided over by Begum Shamsunnahar. Later, under the leadership of this Mahila Bhasha Andolan Samiti, women from all over the district joined the movement and women organized public meetings at different places at different times and demanded that Bengali be made the state language of Pakistan (Ziring, Lawrence, 1971). In Barisal, girls marched in black on February 21.The language movement of the students took the form of a mass movement when the police opened fire on a procession of students in Dhaka that afternoon. The participation of women in this language movement was important in different parts of Bengal (Ziring, Lawrence, 1971).

\section{Demonstration of women's society in Dhaka after the incident on 21st February}

News of police firing on a student procession on 21 February 1952 provoked an extreme reaction on the female community. A large gathering of women led by UniversePG I www.universepg.com
Begum Sufia Kamal, Begum Kazi Motahar Hossain and others was held at Abhaydas Lane No. 12 to protest the firing on innocent students and people of Dhaka. As there was no communication system in the city on that day, old women participated in this meeting on foot from far away. At the meeting, the democratic struggle was declared till Bengali was declared as one of the state languages of Pakistan and no confidence were expressed against the cabinet from that meeting. The meeting strongly condemned those who promoted the movement as an attempt to divide the Bengali-non-Bengali and Hindu-Muslim communities. The meeting demanded proper identification of the martyrs and proper dissemination of information on burial issues. Finally, the meeting adopted a proposal to form an all-party Dhaka Mahila Rashtrabhasha Sangram Parishad (Chatterjee, Basant, 1974).

The girls of Azimpur Colony organized a protest meeting on the night of 23 February 1952 to protest the firing on the student crowd. The meeting was attended by several thousand women from different parts of Dhaka. At the meeting; the women strongly condemned the police killings (Ghatate, 1999). A representative meeting of the women of Dhaka was held in the colony on 25 February. The meeting passed several resolutions protesting the killing of students. And mothers and sisters are urged to continue their struggle till Bengali is accepted as one of the state languages of Pakistan (Parveen, 2010). On 28 February 1952 another meeting of women was held at Purana Paltan. At the meeting, Nurjahan Morshed and writer Laila Samad spoke on the need for women's participation in the language movement. The meeting demanded the establishment of all democratic rights, including freedom of the press, freedom of speech, and the repeal of Article 144 (Gupta, 1974). Women's participation in the language movement increased after the shooting of a student procession on 21 February. In order to involve ordinary women in the movement, the girls of the school and college used to organize public relations in the neighborhoods (The Sunday, February 22, 1987).

From 22 February 1952, female students of schools, colleges and universities embarked on a fundraising campaign to continue the movement for the treatment of the wounded and for the establishment of Bengali as 
the state language (Parveen, 2010).These were the students of the university who were in charge of raising money Sufia Ahmed, Shafia Khatun, Shamsun Nahar, Raushan Ara, Mrs. Khorshedi Alam, Amena Mahmud (Jahan, 1972). Kaiser Siddiqui (Khaliq, 1978). These women went from house to house to raise funds. The housewives expressed their grief and sorrow and donated money. In many homes, women have cried over the loss of loved ones when they heard of students being shot (Rahman, 1993). This means that there was strong support for the language movement of ordinary women in Dhaka. On 23, 24 and 25 February Sara Taifur and Shamsun Nahar raised funds in Azimpur area (Islam, 1994). Sufia Karim, general secretary of the Student Parliament of Eden Girls' College, also took up the task of collecting donations for the treatment and publicity work of the injured students during the February 21 procession (Rahman, 1993).

\section{Women's society outside Dhaka in protest of 21 February incident}

The shooting of the student procession on 21 February 1952 had an effect in different parts of the province besides Dhaka, and when the student movement took the form of a mass movement, the spontaneous participation of women in society could be noticed. After the news of police firing on students in Dhaka spread, a spontaneous procession came out of the school college in Chittagong and women also joined it. The girls of Khastgir Girls School disobeyed the orders of the authorities and joined the procession by crossing the walls of the school. From the procession they strongly protested the killing of students (The Azad, February 28, 1952).

After the police firing on the protesting student procession in Dhaka on 21 February, the women of Sylhet became protesting. On February 22, the women leaders campaigned in different parts of the city and called for unity. On 23rd February, a huge procession of women came out. The procession went around the main roads of the city and ended at Govindacharan Park. At the end of the procession is a meeting. Public leader Yobeda Khatun Chowdhury and other women leaders spoke on the occasion. A gathering of women was held at Jinnah Hall this afternoon. The rally called for the establishment of Bengali as the state language UniversePG I www.universepg.com of Pakistan. On 27 February 1952 a women's procession came out in Sylhet. It was attended by women from all schools and colleges, including women from aristocratic families. From the procession, they protested the police firing on students in Dhaka and demanded proper investigation into the ministers' resignation from the cabinet (Muhith, 1978). On 21 February 1952, Rafiq, Salam, Barkat and Jabbar lost their lives in a police firing on a procession of struggling students in Dhaka centered on the language movement. The spark of that historic event spread to Rajshahi as well. On 22 February, a decision was taken to hold a protest procession and protest meeting in Rajshahi under the leadership of Ataur Rahman.The protest procession and protest meeting Hafiza Begum, Firoza Begum, Hasina Begum and Khuku Palki, 10th class students of PN Gals School, called on the women to join the procession (Islam, 1991).

Then on 23 February 1952, when the procession marched around the city in violation of Section 144, Monwara Begum, a student of PN Girls School, intensified her protest against the dictatorial regime. In response to his call, several thousand girls left the class and joined the procession. The procession was led by 10th class students Hafiza Begum Tuku, Jahanara Begum, Mohsina Begum and others. The teachers inspired the students to participate in the movement. Among the female teachers, Nurmahal Khatun, Hajera Begum, Mansura Begum, Minti, Sneha, Gita, Halima Nirupama played an important role in the girls' movement. The procession ended at Bhubanmohan Park. At the end of the procession, a meeting was held. Monwara Begum and Mohsina Begum made the audience tearful with inflammatory speeches (Monowara Begum on 18 March, 1998). Monwara Begum, a 10th class student of Rajshahi PN Girls School, used to raise money in the mahallas to conduct the movement besides participating in the procession meetings. Hasna Begum, Shamsun Nahar and Begum Jahanara, students of science department of Rajshahi College, played an important role in every stage of the language movement (Haq, 1995). On 25 February 1952, a meeting of school college students was held under the chairmanship of Miss Sabiha Khatun, a second year student of Comilla Victoria College. The meeting condemned the police brutality on the student procession in Dhaka 
and paid homage to the martyrs and prayed for their souls (The Azad, February 26, 1952).

On 28 February 1952, female students of local high schools and madrasas in Bogra organized processions and demonstrations (Parveen, Shahnaj, 2010). On 29 February 1952, protests against the police firing on a student procession in Dhaka were staged in the city on the initiative of the Natore Women's Language Movement Association. From the protest, Shamsunnahar, president of the Natore Women's Council, demanded that Bengali be given the status of the state language of Pakistan (Hannan, Mohammad, 1986). From 21 February 1952 Narayanganj meetings, demonstrations, strikes began. In Dhaka, the movement was gradually intensified in protest of the police firing on the student procession. On 29 February, Mamtaz Begum, the headmistress of Morgan Girls' School and the organizer of the language movement in Narayanganj, was arrested (The Azad, March 9, 1952). As news of his arrest spread, the movement turned into a mass protest. Police took Mamtaz Begum to court on charges of anti-government activities. The student mob then surrounded the court demanding his unconditional release. In this situation, when the police picked up Mumtaz Begum in a car with the intention of taking her to Dhaka, the mob tried to snatch her and enraged the police. Considering the situation, a large number of police were deployed at the spot. As soon as the police reached the spot, clashes started with the crowd. At one stage, when the situation calmed down, the police took Mumtaz Begum to Dhaka Jail. Many women were arrested that day (Paul, Drefus, 1978).

Leena Chakraborty of Palash police station in Narsingdi district protested with the girl's school after receiving news of police on a student procession in Dhaka through newspapers. The procession protested the killing of students and demanded the establishment of Bengali as the state language (Helal et al., 1984). The girls of Pabna district also marched in Dhaka to protest the killing of students by the police and announced that they would continue protesting till Bengal was given the status of state language (Leena Chakraborty's interview on March 1, 1997). On 22 February 1952 a meeting of the girls was held at the premises of the local Kumudini College under the chairmanship of Fahima Yousafzai. The meeting highUniversePG I www.universepg.com lighted the importance of women's participation in the language movement and announced that the movement would continue until Bengali was given the status of the state language of Pakistan (Information obtained from Dipti Lohani's interview on June 13, 1998). The decision to march was taken at the meeting on 23rd February (The Azad, February 27, 1952). Then the college girls led by Hamida Begum, Mrs. Aziza Begum Moni, Mrs. Mahmuda Khanam, Ruby, Sufia Begum, Jonna Begum, Jharna Khatun and Saleha marched in Tangail. The procession condemned the government of Pakistan for not giving Bengali the status of state language (Nurunnahar Begum's interview on June 24, 1998). When the tide of language movement spread across the country in 1952, it also affected the city of Khulna. At this time the movement of Khulna city like other cities started.At this time the movement started in Khulna city like other cities (The Weekly Bichitra, February 21, 1988). The girls write posters in different colors and stick them on the walls in the dark of night. School and college girls closed their classes and started rallies, meetings and rallies in the streets. The movement led by Anwara Khatun, Lutfunnahar, Fatema Chowdhury, Sajeda Helen and Sufia Ali quickly spread throughout the city (Dey, 1996).

\section{Language movement in Dhaka in the following years} On 21 February 1953, the first women's morning ferry left Dhaka. All the leading women including Sufia Kamal took part in it. Countless school-college girls of Dhaka city took part in it. Dhaka University students take out separate processions. Many city girls take out processions outside Dhaka city (Rokya Mahbub's interview on May 28, 1998). After 1954, these processions became bigger. On 21 February 1954, under the leadership of Shamima in Bogra, the girls wanted the state language Bengali; they wanted the release of political prisoners. The girls in the procession demanded justice for those killed in police shootings on 21 February 1952 (Rahman et al., 1990). Language Day was observed on February 21, 1955. On that day, Farida Bari, Kamrun Nahar Laili, Firoza Begum, Jahrat Ara, Latifa Khanam and countless other women were imprisoned in Dhaka under the name of Ganakantha Dhal and for demanding Bengali language (Sufia Ali's interview on May 28, 1998). The move- 
ment gradually became so bizarre that the government of Pakistan realized that the language movement could not be stopped. The demand for the state language Bengali must be accepted. Thus, it can be said that as a result of the movement, on February 21, 1955, Section 92A came to an end (Ziring, Lawrence, 1971). Therefore, in the first constitution of Pakistan in 1956, the ruling party of Pakistan was compelled to recognize Bengali as the state language. At the same time, it was the first step in the path of Bengali nationalism established by the blood of this movement of girls. At every level, the participation of Bengali women's society was very important.

\section{CONCLUSION:}

The participation of Bengali women in the Bengali language movement has set a shining example. The participation of women in the Bengali language movement with the students is the first step in establishing the rights of Bengalis. In order to establish Bengali as the mother tongue as the state language, women vibrated the streets in processions. The mothers and sisters of Bengal conveyed the firm oath of the language movement in every house by holding meetings and forming Sangram Parishads in the neighborhoods. When conservative Bengali women took to the streets to protect the dignity of their mother tongue, ignoring the veil, the male society could not stay at home. So this movement of men and women together quickly turned into a sea of people. The participation of women in the movement on February 21, 1952 was the best. In order to demand the blood of Shaheed Bhai in the police firing, the women have taken position on the highway ignoring the bloody eyes of the ruling party. Innocent Bengali women of this country have fought like heroes rather than die voluntarily for fear of being brutally oppressed by the ruling class. Many mothers have sent their sons and daughters to fight, thinking that it is better to fight like a hero than to die voluntarily. The inevitable result of the participation of Bengali women in this movement was the defeat of the ruling Muslim League in the 1954 provincial elections in East Bengal. This self-sacrifice of Bengali women has been recognized internationally today. It recognizes the mother tongue rights of all language-speaking peoples in the world. According to the decision of UNESCO, Ekushey February is being celebrated today as the International Mother Language Day. Even Pakistan, which did not give Bengali the status of state language, is celebrating Ekushey February as Mother Language Day. Therefore, it can be said that this historical role of Bengali women's society in the Bengali language movement has become an example to be followed by every exploited and disenfranchised nation.

\section{ACKNOWLEDGEMENT:}

We would like to thank Mr. Md. Shaon Akter for valuable comments, suggestions and help in this research.

\section{CONFLICTS OF INTEREST:}

The author's declared there are no conflicts of interest to publish it.

\section{REFERRENCES:}

1) Ahmed, Kabir, (1972). Break up of Pakistan, London, The Social Science Publisher, p.67.

2) Ahmed, Monwar, (1993). Illustrated Document in Language Movement, Dhaka, Agamany publication, pp.86, 98.

3) Ali, Mehrab, (1965). History of Political Movement in Dinajpur, Dinajpur, Nowroz Sahitya Majlis, pp.35-43.

4) Amin, Md. Ruhul, (1996). 'Effectiveness of Parliamentary System in Bangladesh: A Survey', Unpublished M.Phil Thesis, Rajshahi: Rajshahi University, p.18.

5) Asad, Asaduzzaman, (1989). History of Jessore District, Dhaka, Sher-e-Bangla Nagar, pp.111-112.

6) Ayoob, A.K.M. (1971). Bangladesh: Struggle for Freedom, Varanashi, Indian Press, p.57.

7) Begum, Maleka, (1989). The Women's Movement of Bengal, Dhaka, The University Press Limited, pp.152, 153.

8) Bose, Nemai Sadhan, (1974). The Indian Movement: an Outline, Calcutta, D.N. Basa at Ananda Press \& Publication Pvt., pp.78-79.

9) Chatterjee, Basant, (1974). Inside Bangladesh Today: An eyewitness, New York, International Publication Service, p.70.

10) Choudhury, G.W. (1974). The last days of United Pakistan, London, C. Hurst and Co., p.87. https://www.jstor.org/stable/3990586 
11) Choudhury, Subrata, (1972). The Genesis of Bangladesh, New York, Asia Publishing House, p.89.

https://estudiosdeasiayafrica.colmex.mx/index.p hp/eaa/article/view/269

12) Deshpande, G.P. (1971). Bangladesh-a Struggle for Nationhood, Delhi, Vikas, p.97.

13) Dey, Tapan Kumar, (1996). Tangail in the War of Liberation, Dhaka, Jagrati Publications, p.26.

14) Falguni, Aditi, (1997). The Women's Struggle in Bengal, Dhaka, Steps Stewards Development, p.22.

15) Ghatate, N.M. (1999). Language Monument in East Pakistan, New Delhi, Books Service, pp.85-97.

16) Gupta, Jyoti Sen, (1974). The History of Freedom Movement in Bangladesh, 1943-1973, Calcutta, Naya Prokash, p.99.

https://www.scribd.com/document/158563324/H istory-of-Freedom-Movement-in-Bangladesh-19 47-1973-Jyoti-Sen-Gupta

17) Hannan, Mohammad, (1986). History of Student Movement in Bangladesh, Dhaka, National Literary Publications, pp.54, 56,127 \& 128.

18) Haq, Muhammad Ekramul, (1995). Rajshahi District Language Movement and Others Context, Dhaka, Bangla Academy, pp.16 \& 45-46.

19) Haque, Gaziul and Mukul, M.R. Akhtar, (1991). Language Movement, Dhaka, Haqqani Publications, pp. 37, 38.

20) Helal et al. (1984). History of the Language Movement, Dhaka, Bangla Academy, pp.166, $167,171,175,177,187,215,216,217,218$, 282, 287, 289, 304, $312 \& 467$.

21) Islam, Mustafa Nurul, (1984). Mother Tongue Consciousness and Language Movement, Dhaka, National Library, pp.153, 207.

22) Islam, Shafiqul, (1991). Language Movement in Rajshahi, Rajshahi, Ekta Mudran, p.118.

23) Islam, Tajul, (1994). Language Movement in Sylhet, Dhaka, Sahitya Prakash, pp. 26, 59 \& 60.

24) Jahan, Rounaq, (1972). Pakistan: Failure in National Integration, New York, Columbia University Press, pp.76-79.
25) Kamal, Mostafa, (1987). Language movement: forty-seven to fifty-two, Dhaka, Bangladesh Co-Operative Society, pp. 216-219, 368 \& 371-372.

26) Karim, Md. Rajaul \& Amin, Ruhul, (1916). Hindhu-Muslim Relation in Bengal, 17751916, Rajshahi, Uttron Prokasiny, pp.17-48.

27) Khaliq, S.A. (1978). Pakistan -Peace and War, New Delhi, The English Book store, 1978, pp. 55-57.

28) Khan, Saadullah, (1975). East Pakistan to Bangladesh, Lahore, Lahore Law Times Publications, p.67.

29) Makinley, Jim, (1979). Death to life Bangladesh, Dhaka, Immanual Baptist Church, p.72.

30) Mankeker, D.R. (1971). Pak Colonialism in Est Bengal, New Delhi, Somaiya Pub. Pvt. Ltd., p.77.

https://archive.org/stream/in.ernet.dli.2015.1366 58/2015.136658.Pak-Colonialism-In-East-Beng al_djvu.txt

31) Matin, Abdul and Rafiq, Ahmad, (1991). History of Language Movement, Dhaka, Jatiya Sahitya Prakashani, pp. 167,183.

32) Muhith, A.M.A. (1978). Bangladesh-Emergence of a Nation, Dhaka, Bangladesh Books International Ltd., p.93.

https://muhith.info.bd/pdf/bangladesh\%20emerg ence\%20of\%20a\%20nation.pdf

33) Mumtaz, Khawar \& Shaheed, Farida, (1987). Women of Pakistan, London, Zed Books Ltd., p.55. https://philpapers.org/rec/MUMWOP

34) Nanda,B. R. (1975). Indian Women from Purdah to Mordernity, New Delhi, Vikas Publishing House Pvt. Ltd., pp.16-18.

35) Parveen, Shahnaj, (2010). Contributions of Women to the Liberation War of Bangladesh, Dhaka, Bangla Academy, pp.10, 30, 31, 33, 34, 36, 37.

36) Paul, Drefus, (1972). Pakistan and Bangladesh, Paris: Arhould, p.77.

37) Rahman, Ataur and Hashemi, Syed, (1990). Class Position of Participants in Language Movement, Dhaka, University Press Ltd., p.101.

38) Rahman, Mahfuzur, (1993). Bengali Nationalist Struggle in the War of Liberation Chitta- 
gong, Chittagong, Bangladesh Liberation War Research Center, p.201.

39) Sarkar, Sir Jadunath, (1972). History of Bengal (1200-1757), Dhaka, The University of Dhaka, pp.481-499.

40) Shamsuzzaman, Abul Fazl, (1992). The Story of Language Movement and Liberation War, Dhaka, Trivij Publications, pp. 14, 15.

41) Singh, Khushwant, (1976). War and Peace in Indian Pakistan Bangladesh, Delhi, UBS Publisher, p.76.

https://core.ac.uk/download/pdf/11821495.pdf

42) Sultana J., and Amin MA. (2020). Historic 7th March Speech of Bangabandhu: Democracy and Civility in Leadership, Asian J. Soc. Sci. Leg. Stud., 2(2), 33-40. https://doi.org/10.34104/ajssls.020.033040

43) Symonds, Richard, (1915). The Making of Pakistan, Karachi, Allies Book Corporation, p142.

44) Umar, Badruddin, (1979). East Bengal Language Movement and the Politics of the Time, Dhaka, Maula Bradas, pp. 74, $79 \& 94$.
45) Zamal, Hasan, (1971). East Pakistan crisis and India, Dhaka, Pakistan Academy, p.78.

46) Ziring, Lawrence, (1971). The Ayub Khan Era Politice in Pakistan, 1958-1969, New York, Syracuse University Press, pp.31-37.

47) Ziring, Lawrence, (1971). Politics in Pakistan, 1947-1969, New York, Syracuse University Press, p.128. https://doi.org/10.1177/097492847202800420

\section{Interview}

a) Fatema Chowdhury's interview on May 25, 1998.

b) Leena Chakraborty's interview on March 1, 1997.

c) Monowara Begum on August 16, 1998.

d) Monowara Begum on March 18, 1998.

e) Rokya Mahbub's interview on May 28, 1998.

f) Sufia Ali's interview on May 28, 1998

g) Lohani'sinterview on June 13, 1998.

h) Nurunnahar Begum's interview on June 24, 1998.

\section{News Paper}

a) The Azad.

b) The Holiday.

c) The Sunday Time.

d) The Weekly Bichitra.

Citation: Karim MR., and Akter MS. (2021). The contribution of women in the Bengali language movement (1952): a historical analysis, Br. J. Arts Humanit., 3(5), 116-127. https://doi.org/10.34104/bjah.02101160127 @ @ 